Anais da Academia Brasileira de Ciências (2006) 78(3): 475-484

(Annals of the Brazilian Academy of Sciences)

ISSN 0001-3765

www.scielo.br/aabc

\title{
Acidification of the parasitophorous vacuole containing Toxoplasma gondii in the presence of hydroxyurea
}

\author{
CRISTIANE S. CARVALHO and EDÉSIO J.T. MELO \\ Laboratório de Biologia Celular e Tecidual, Centro de Biociências e Biotecnologia \\ Universidade Estadual do Norte Fluminense, Av. Alberto Lamego 2000 \\ 28013-602 Campos dos Goytacazes, RJ, Brasil \\ Manuscript received on March 3, 2006; accepted for publication on March 22, 2006; \\ presented by WANDERLEY DE SOUZA
}

\begin{abstract}
Toxoplasma gondii multiplies within parasitophorous vacuole that is not recognized by the primary no oxidative defense of host cells, mainly represented by the fusion with acidic organelles. Recent studies have already shown that hydroxyurea arrested the intracellular parasites leading to its destruction. In the present work we investigated the cellular mechanism involved in the destruction of intracellular Toxoplasma gondii. Fluorescent vital stains were used in order to observe possible acidification of parasitophorous vacuole-containing Toxoplasma gondii in presence of hydroxyurea. Vero cells infected with tachyzoites were treated with hydroxyurea for 12, 24 or 48 hours. Fluorescence, indicative of acidification, was observed in the parasitophorous vacuole when the cultures were incubated in presence of acridine orange. LysoTracker red was used in order to determine whether lysosomes were involved in the acidification process. An intense fluorescence was observed after 12 and 24 hours of incubation with hydroxyurea, achieving it is highly intensity after 48 hours of treatment. Ultrastructural cytochemistry for localization of the acid phosphatase lysosomal enzyme was realized. Treated infected cultures showed reaction product in vesicles fusing with vacuole or associated with intravacuolar parasites. These results suggest that fusion with lysosomes and acidification of parasitophorous vacuole leads to parasites destruction in the presence pf hydroxyurea.
\end{abstract}

Key words: Hydroxyurea, Toxoplasma gondii, parasitophorous vacuole.

\section{INTRODUCTION}

Toxoplasma gondii is a cosmopolitan protozoan parasite able to invade and replicate within nucleated cells of vertebrates (Tenter et al. 2000, Hill and Dubey 2002). Following invasion of host cells the infective form of Toxoplasma gondii - tachyzoites - resides within membrane-bound vacuoles known as parasitophorous vacuole (PV) (Sibley et al. 1985, Sinai and Joiner 1997, Beyer et al. 2002).

Correspondence to: E.J.T. Melo

E-mail: ejtm@uenf.br
Intracellular vacuoles usually undergo fusion with acidic organelles as lysosomes and endosomes, leading to acidification and digestion of intravacuolar materials (Tjeiie et al. 2000). The lysosome fusion with vacuoles also is the primary no oxidative defense of the host cells against intracellular parasites (Kornfeld and Mellman 1989). However, PV containing $T$. gondii avoids fusion with acidic organelles as lysosomes and endosomes (Hirsch and Jones 1972, Finlay and Falkow 1989, Joiner et al. 1990, Sibley 1993) and this characteristic is responsible for the intracellular survival of the parasite. 
Early studies showed that intravacuolar parasites as T. gondii are eliminated of host cells in presence of hydroxyurea (Melo et al. 2000, Melo and Beiral 2003). In the present study we showed the cellular mechanism involved in the elimination of intracellular T. gondii. Understanding the interactions of this vacuole with the host cell is important, since they are one of the keys to successful intracellular parasitism.

\section{MATERIALS AND METHODS}

\section{PARASITES}

Tachyzoites from the virulent RH strain of Toxoplasma gondii were maintained by intraperitoneal passages in Swiss mice and were collected in Ringer's solution at $\mathrm{pH} 7.2,48$ hours after infection. The collected fluid was centrifuged at $200 \mathrm{~g}$ for 10 minutes at room temperature to remove cells and debris. The supernatant containing the parasites was centrifuged at $1,000 \mathrm{~g}$ for 10 minutes. The pellet obtained was washed twice with phosphatebuffered saline solution (PBS), $\mathrm{pH} \mathrm{7.2,} \mathrm{and} \mathrm{resus-}$ pended to a density of $10^{7}$ parasites $/ \mathrm{ml}$ in medium 199 without fetal calf serum (FCS). The parasites were used within 30 minutes after removal from infected animals, and the viability was evaluated using a dye-exclusion test with Trypan blue.

\section{Host CELL}

Vero cells (kidney fibroblast of African green monkey) were maintained in Falcon plastic flasks, in medium 199 supplemented with 5\% fetal calf serum (FCS) and passed by trypsinization when the cell density approached a confluent monolayer. One day before being used in the experiments, approximately $2 \times 10^{4}$ Vero cells were placed on 24-well tissue cultures plates that contained a round sterile coverslip, or were plated into flasks $25 \mathrm{~cm}^{2}$ $\left(3-5 \times 10^{6}\right.$ cells/flasks) and maintained at $37^{\circ} \mathrm{C}$ overnight in $5 \% \mathrm{CO}_{2}$.

\section{Cell-PARASite InTERACTION}

Parasites suspended in medium 199 were incubated for $2 \mathrm{~h}$ in the presence of Vero cells using a 5:1 parasite-host cell ratio. After that, the cells were washed twice with PBS to remove extracellular parasites and incubated for 24 hours at $37^{\circ} \mathrm{C}$ in $5 \% \mathrm{CO}_{2}$.

\section{HYDROXYUREA}

Stock solution of Hydroxyurea (Merck Chemical Co.) was dissolved in PBS at concentration of $4 \mathrm{M}$. The hydroxyurea (HU) solution was dissolved in medium 199 with $5 \%$ fetal calf serum at concentration of $4 \mathrm{mM}$ as described by Melo et al. (2000). This solution was used in same day. Hydroxyurea was added in the infected Vero cells for 12, 24 and 48 hours. After that, the cultures were processed to light and transmission electron microscopy as described below.

\section{LIGHT MICROSCOPY}

The cultures were washed three times with PBS, fixed with Bouin's solution, and stained with Giemsa. All preparations were examined using Zeiss AXIOPLAN photomicroscope equipped with objective $63 x$.

\section{LASER ScAn CONFOCAL FluORESCEnCE MICROSCOPY}

In order to observe acidic compartments infected cultures were incubated with acridine orange (Sigma Chemical Co.) or Lyso-tracker red (Molecular Probes, Inc.) - the lysosomes specific probe. Acridine orange $(5 \mu \mathrm{g} / \mathrm{ml})$ was added to the medium 199 without FCS and added to the cultures for $30 \mathrm{~min}$ at $37^{\circ} \mathrm{C}$, as previously described by Kielian and Cohn (1980). The cultures were washed with medium 199 and the cells were examined at a Zeiss Confocal Laser Scan Microscope (CLSM), using an argon laser $488 \mathrm{~nm}$ or $543 \mathrm{~nm}$. Lyso-tracker red $(50 \mathrm{nM})$ was added in the medium 199 without FCS and added to the cultures for 30 minutes, at $37^{\circ} \mathrm{C}$. Then the culture was washed in medium 199 without FCS and observed in confocal microscopy 


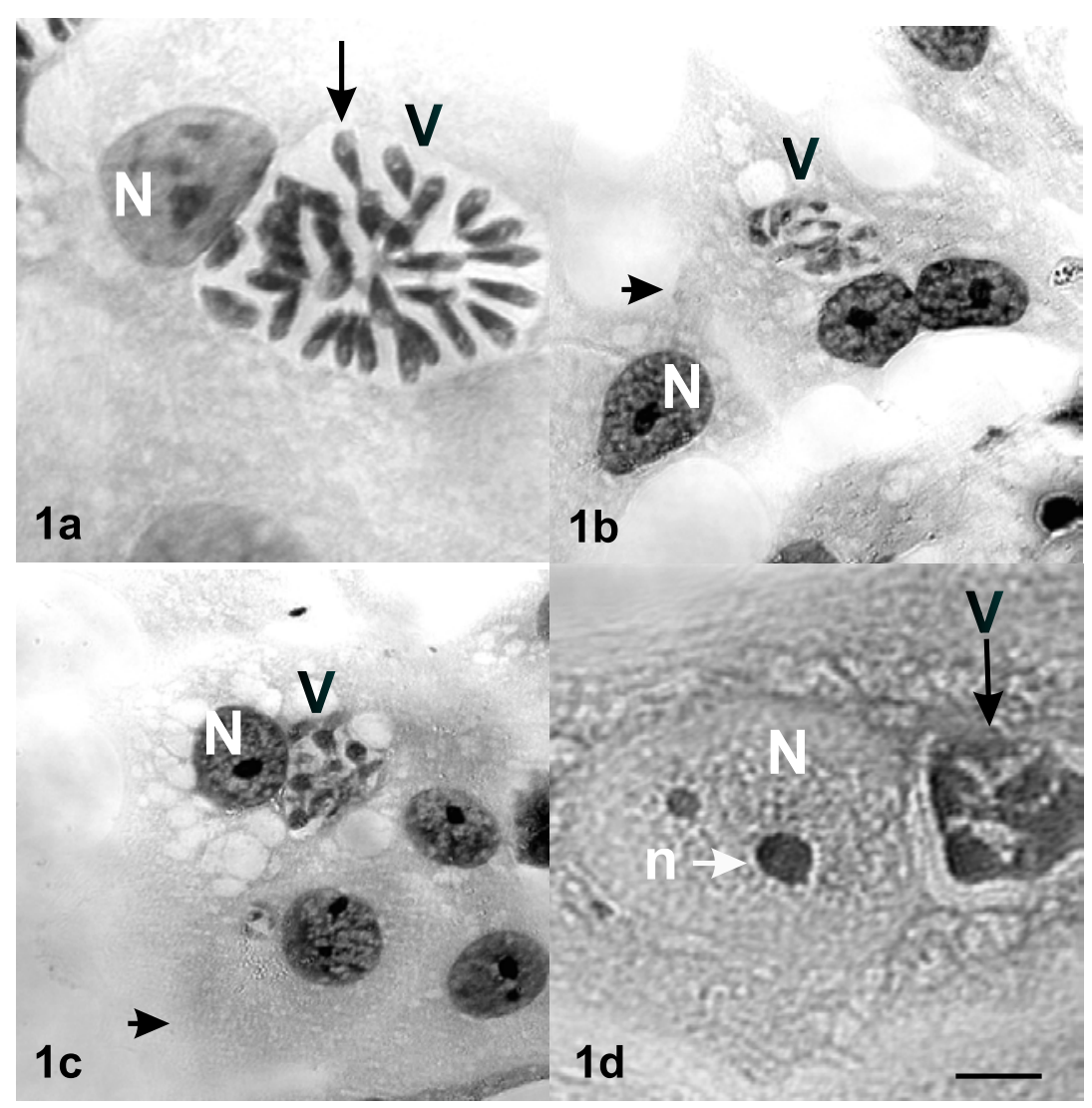

Fig. 1 - Giemsa-stained Vero cells infected with tachyzoites of $T$. gondii for 24 h (fig. 1a). Parasites with crescent-shaped multiplies inside parasitophorous vacuole (V). During incubation for $12 \mathrm{~h}$ (fig. 1b), 24h (fig. 1c) or $48 \mathrm{~h}$ (fig. 1d) with hydroxyurea, tachyzoites had undergone drastic morphological alterations while host cell were not affected. Tachyzoytes: arrow; Host cell: arrowhead; Parasitophorous vacuole: V; Nucleus: N; Nucleolus: n. Bar: $7 \mu \mathrm{m}$.

using an argon laser 543nm. Photographs were taken from the monitor on Tri-X (ASA 100) film using the automatic exposure control of the Zeiss camera. Tri- X film was developed for 5 minutes in Kodak HC 110 (dilution B).

\section{TRANSMission ELECTRON MicRoscopy}

Infected Vero cells cultivated as described above were incubated with hydroxyurea. For detection of acid phosphatase activity (Robinson and Karnovsky 1983) the cells were fixed for $30 \mathrm{~min}$ at $4^{\circ} \mathrm{C}$ in $1 \%$ glutaraldehyde with $0.1 \mathrm{M}$ cacodylate buffer ( $\mathrm{pH}$ 7.2). They were rinsed in buffer and pre-incubated at $37^{\circ} \mathrm{C}$ for 30 minutes in medium containing $2 \mathrm{mM} \mathrm{CeCl} 3,5 \%$ sucrose and $0.05 \mathrm{M}$ Tris-maleate buffer ( $\mathrm{pH}$ 5.0). Thereafter, the cells were incubated at $37^{\circ} \mathrm{C}$ for 60 minutes in medium containing $2 \mathrm{mM} \mathrm{CeCl} 3,7 \mathrm{mM} \mathrm{Na}-\beta$-glycerophosphate, $5 \%$ sucrose and $0.05 \mathrm{M}$ Tris-maleate buffer (pH 5.0). Control cells were incubated in medium in the absence of the substrate.

After incubation, the cells were rinsed in cacodylate buffer, re-fixed in a solution containing $4 \%$ paraformaldehyde and $1 \%$ glutaraldehyde in cacodylate buffer ( $\mathrm{pH} 7.2)$ for $1 \mathrm{~h}$ at $37^{\circ} \mathrm{C}$, postfixed with osmium tetroxide, dehydrated in acetone and embedded in Epon. Thin sections not stained with uranyl acetate and lead citrate. The sections 
were observed with Zeiss 900 electron microscope, at $50 \mathrm{KV}$.

\section{RESULTS}

Cultures of Vero cells were initially allowed to interact with tachyzoites of $T$. gondii for $24 \mathrm{~h}$ at $37^{\circ} \mathrm{C}$. Under these conditions, most of the cells were infected with tachyzoites of $T$. gondii. After this $24 \mathrm{~h}$ period, some of these cultures were treated with $4 \mathrm{mM}$ of hydroxyurea for $12 \mathrm{~h}, 24 \mathrm{~h}$ or $48 \mathrm{~h}$. Morphological aspects of parasites included crescentshaped cells with about $6 \mu \mathrm{m}$ long and $2 \mu \mathrm{m}$ wide (Fig. 1a-arrow). The incubation of the infected cultures with hydroxyurea for 12h (Fig. 1b) led to drastic morphological alterations on the intravacuolar parasites. After 24h (Fig. 1c) and 48h (Fig. 1d) of drug incubation parasites were totally disorganized. However, the host cell was no affected (Fig. 1b, c - arrowhead) and normal nucleus and nucleolus were observed (Fig. 1b, d-N, n). The progressive destruction of intracellular parasites resulted in decrease of parasitophorous vacuole volume (Fig. 1c, d-V).

In order to analyze if the destruction of tachyzoites involved vacuole acidification, the cultures were incubated with fluorescent stain acridine orange (Fig. 2). In untreated infected cells (Fig. 2a, b), an intense fluorescence was observed around PV (Fig. 2a - arrow) and dispersed in the cytoplasm of host cell (Fig. 2a - arrowhead); however, no fluorescence signal was observed inside PV. After incubation of $\mathrm{HU}$ for $12 \mathrm{~h}$ (data not shown) and 24h (Figs. 2c, d, e), acidification of PV containing $T$. gondii was observed as showed by the fluorescence pattern of acridine orange (Fig. 2c, 2d, arrowhead). An intense fluorescence was also observed inside PV after $48 \mathrm{~h}$ (data not shown). The advantage of using acridine orange probe is the possibility of two-fluorescence spectrum emission in acidic medium as demonstrated by Kielian and Cohn (1980). Therefore, in the treated host cells, acidic compartments and PV containing parasites emitted distinct wavelengths: the Rhodamine-like spectrum as positive indicative of acidification (Fig. 2c, arrowhead) and the Fluorescein-like spectrum as indicative of the neutral pH of the PV (Fig. 2d).

In order to determine whether lysosomes were involved with acidification of PV containing parasites in the presence of HU, LysoTracker red - a specific lysosome probe - was used (Fig. 3). Untreated host cells infected or not with $T$. gondii showed punctual fluorescence indicative of lysosomes dispersed throughout the cytoplasm (Fig. 3a, $\mathrm{b}$ arrow). As observed with acridine orange, intravacuolar parasites were not labeled (data not shown). However, progressive fluorescence patterns were observed after incubation of HU for 12 (Fig. 3c, d - arrow) and 24h (Fig. 3e, f - arrow), where the intravacuolar medium and parasites became fluorescent. The most intense fluorescence was observed in the PV of cultures treated for 48h (Fig. $3 \mathrm{~g}$ - arrow) where a large number of lysosomes was observed in the cytoplasm (Fig. 3g, h-arrowhead).

The possibility of the acidic phosphatase activity during tachyzoites elimination in the presence of $\mathrm{HU}$ was also tested by using ultrastructural cytochemistry (Fig. 4). After 12h of drug incubation the reaction product, indicative of phosphatase presence, was observed in the cytoplasm (Fig. 4a - arrowhead) and within PV (Fig. 4a - inset). After $24 \mathrm{~h}$ in presence of $\mathrm{HU}$ the reaction product was observed on the parasite surface (Fig. $4 \mathrm{~b}-$ arrow) and $48 \mathrm{~h}$ after drug incubation, the reaction product was associated with disrupted intravacuolar parasite (Fig. $4 \mathrm{c}-$ arrow).

These results suggested that in the presence of HU Vero cells promote acidification of PV-containing tachyzoites leading to lysosome fusion with PV and discharge of phosphatase enzymes into lumen of this vacuole.

\section{DISCUSSION}

During and after invasion of the host cell, Toxoplasma gondii secretes several compounds that lead to changes in the biochemical nature of the vacuole 


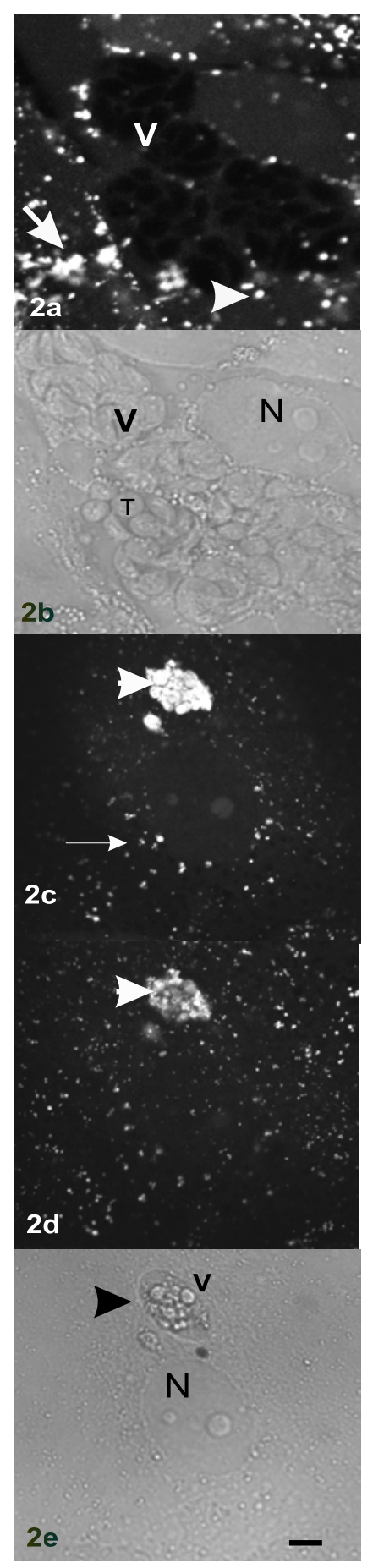

Fig. 2 - Confocal laser scanning microscopy of infected cells in the presence of Acridine Orange $(5 \mu \mathrm{g} / \mathrm{ml})$ for $30 \mathrm{~min}$. Infected cells did not show fluorescence inside PV containing parasites (fig. 2a, b-V). In the presence of hydroxyurea for 24h (fig. 2c-e), fluorescence was observed inside PV containing disorganized parasites (fig. 2e - arrowhead). The fluorescence was indicative of acidification (Rhodomine spectrum, fig. 2c) or indicative of the neutral pH of the PV (Fluorescein spectrum. Fig. 2d). Parasitophorous vacuole: V; Nucleus: N; Tachyzoytes: T. Bar: $5 \mu \mathrm{m}$. 

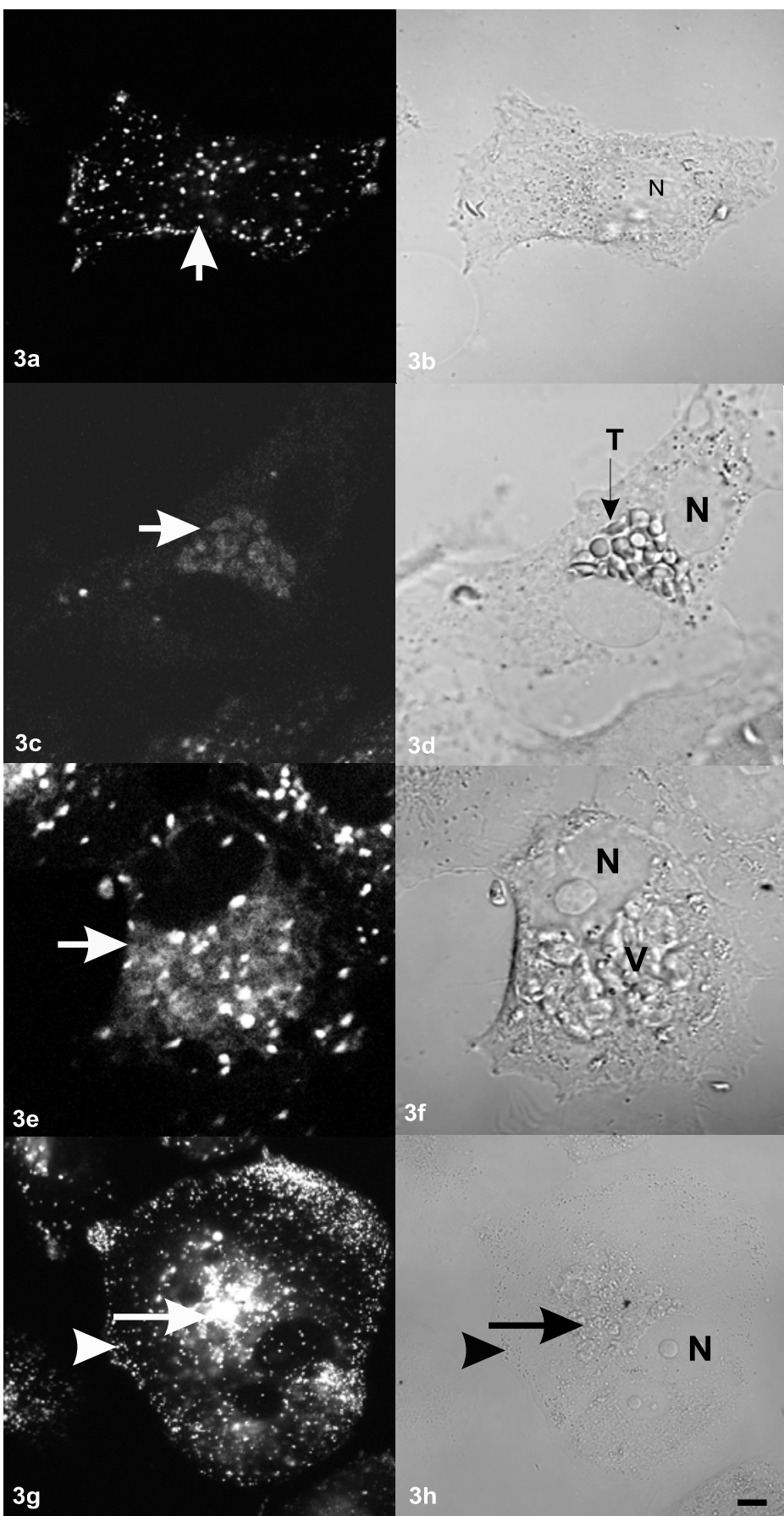

$3 f$

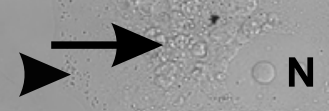

$3 \mathrm{~h}$

Fig. 3 - Confocal laser scanning microscopy of infected in the presence of Lyso Tracker red (50nm) for 30 minutes. Punctual fluorescence could be observed at the cytoplasm in untreated host cell (fig. 3a, b-arrowhead). However, a progressive fluorescence inside PV containing tachyzoites was observed after incubation for $12 \mathrm{~h}$ (fig. 3c, d-arrow), 24h (fig. 3e, f - arrow) or 48h (fig. 3g, h - arrow) in presence of HU as indicative PV-lysosomes fusion. Tachyzoytes: T; Nucleus: N; Parasitophorous vacuole: V. Bar: $5 \mu \mathrm{m}$. 


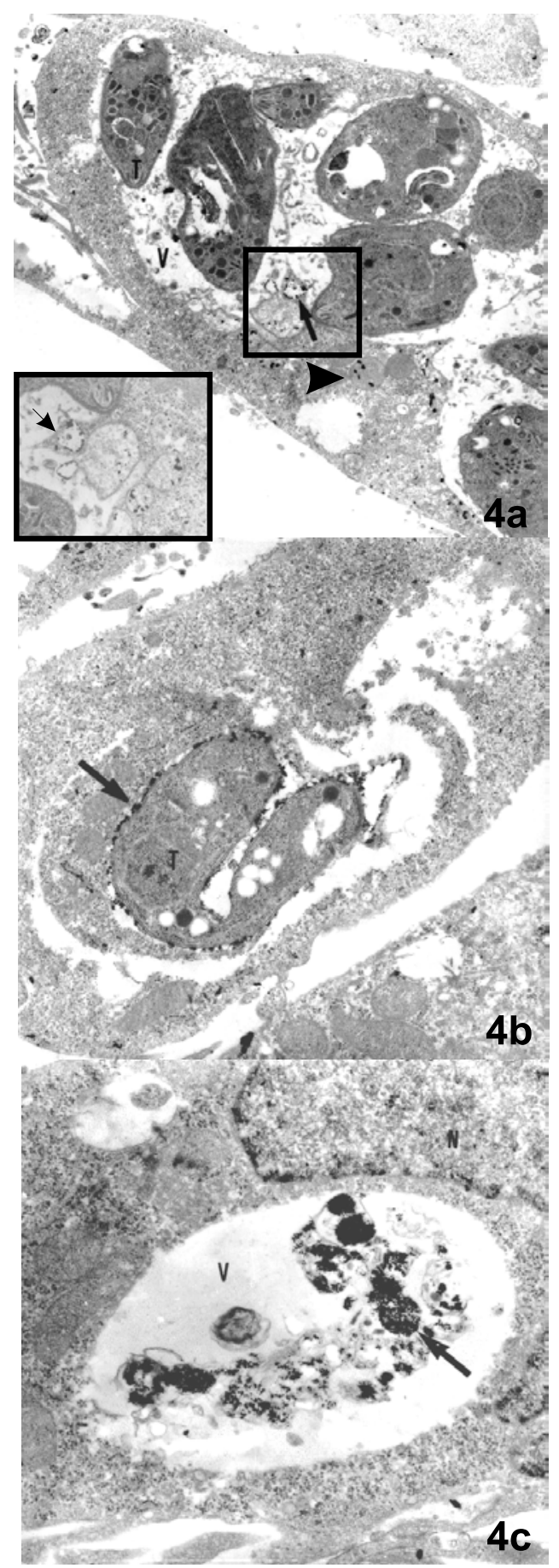

Fig. 4 - Transmission electron microscopy of Vero cells subjected to the acidic phosphatase technique. In the presence of hydroxyurea for $12 \mathrm{~h}$, infected cells showed reaction product in cytoplasm (fig. $4 \mathrm{a}$ - arrowhead) or in the vesicle fusing with PV (fig. 4a, inset arrow). After $24 \mathrm{~h}$ of incubation with the drug the reaction product could be observed on parasite surface (fig. $4 \mathrm{~b}-$ arrow) or associates with disrupted parasites (fig. $4 \mathrm{c}$ - arrow) when the infected cells were incubated for $48 \mathrm{~h}$. Tachyzoites: T; Parasitophorous vacuole: V; Nucleus: N. Figure 4a =x7000; inset $=x 12000$; Figure $4 b=x 12000$; Figure $4 c=x 20000$. 
membrane where it resides, called parasitophorous vacuole $(\mathrm{PV})$. Protected in an intravacuolar space tachyzoites multiply until rupture of the host cell. Vacuole-lysosome membrane fusion is a highly regulated event that is essential for intracellular killing of microorganisms.

The pioneering studies of Hirsch and Jones (1972) demonstrated that replicating parasites internalized by macrophages were in vacuole did not fuse with thorotrast-loaded lysosomes. Sibley et al. (1985) complementing Jones and Hirsch studies, demonstrated that PV-containing T. gondii did not fuse with endocytic organelles and that this feature was dependent of the viability of the parasite. Joiner et al. (1990) showed that killing the intracellular parasite after entry did not reverse the fusion incompetence of the vacuole and that this fusion incompetence is established at the time of parasite entry, during its active invasion (Mordue et al. 1999a).

However, the inactivation of the enzyme ribonucleotide reductase and the synthesis of DNA with hydroxyurea (Yarbro 1992) led to some intracellular parasites elimination including $T$. gondii (Melo et al. 2000, Melo and Beiral 2003). In present studies, intravacuolar $T$. gondii is eliminated in presence of $\mathrm{HU}$ while the fusion PV containing tachyzoites with lysosomes is established leading acidification of PV and tachyzoites degradation, as now demonstrated using vital fluorescent probes (Swanson 1989, Tuma et al. 2001, Magez et al. 1997). However, this parasite degradation in presence of HU may be connecting with lost of parasite viability. In this case, $T$. gondii would not maintain PV-modification, becoming this vacuole susceptible to primary oxidative defense of the host cells, leading to parasites digestion.

The important point that during intracellular infection, parasitophorous vacuole containing $T$. gondii was susceptive to fuse with acidic vesicles - an important microbicide system - in presence of hydroxyurea, suggesting that the PV-fusion incompetence is established during intravacuolar parasite development and not only during parasite entry, as showed for Joiner et al. 1990. Therefore, our results also demonstrated that vesicles containing acidic enzymes were competence to fuse with PV-containing tachyzoites in presence of HU suggesting that the lost of parasite features to avoid the PV-acidic vesicles fusion. Thus, the multiplication interruption and elimination of intracellular parasites was possible in the presence of $\mathrm{HU}$, resulting in lysosomes vacuole-fusion.

Although parasitophorous vacuole containing viable $T$. gondii have been shown to resist to fusion with the endocytic and exocytic pathways of the host cell (Mordue et al. 1999a), this compartment also has the capacity to interact with host cell mitochondria, endoplasmic reticulum (Melo et al. 1992, Sinai et al. 1997, Melo and De Souza 1997) and microtubules (Melo et al. 2001), and capture C6NBD-Ceramide products during intracellular parasites development (Melo and De Souza 1996). However, the avoidance of endocytic fusion and selective recruitment of host cell organelles and nutrients from host cells are well known strategies used by intracellular bacterial and other pathogens (Horwitz 1984, Matsumoto et al. 1991). Understanding the formation and modification of PV-containing T. gondii may reveal novel mechanisms that lead to intracellular survival.

Melo and Beiral (2003) had already demonstrated that in the presence of HU host cells eliminated Trypanosoma cruzi and Leishmania amazonensis, although the cellular mechanisms involved in parasite elimination were not determined in the present study. Finally, the possibility of using the cellular action in the presence of $\mathrm{HU}$ to defense of the organism against toxoplasmosis and other diseases will also going to be tested in our laboratories.

\section{ACKNOWLEDGMENTS}

The authors thank Miss Andréa Carvalho César, Andrea C. Vetö Arnholdt and Carlos Eduardo Veiga de Carvalho for suggestions regarding the preparation of the manuscript. This work was supported by Fundação Carlos Chagas Filho de Amparo à Pesquisa do Estado do Rio de Janeiro (FAPERJ). 
They also thank Coordenação de Aperfeiçoamento de Pessoal de Nível Superior (CAPES) for the student fellowships.

\section{RESUMO}

Toxoplasma gondii se multiplica dentro do vacúolo parasitóforo que não é reconhecido pela defesa primária não oxidativa de células hospedeiras: a fusão com organelas ácidas. Estudos anteriores mostraram que hidroxiuréia interrompeu a multiplicação dos parasitos intracelulares causando sua eliminação. No presente trabalho nós investigamos o mecanismo celular envolvido na destruição do Toxoplasma gondii intracelular. Marcadores vitais fluorescentes foram usados para observar a possível acidificação do vacúolo parasitóforo contendo Toxoplasma gondii na presença de hidroxiuréia. Células Vero infectadas com taquizoítos foram tratadas com hidroxiuréia por 12, 24 ou 48 horas. Fluorescência indicativa de acidificação foi observada no vacúolo parasitóforo quando as culturas foram incubadas na presença de laranja de acridina. Lyso Tracker red foi usado para determinar se os lisossomos estavam envolvidos no processo de acidificação. Uma fluorescência intensa foi observada depois de 12 e 24 horas de incubação com hidroxiuréia, alcançando uma intensidade maior após 48 horas de tratamento. Citoquímica ultraestrutural para localização da enzima fosfatase ácida lisossomal foi realizada. As culturas infectadas e tratadas apresentaram produto de reação em vesículas se fundindo com o vacúolo ou associado com parasitas intravacuolares. Estes resultados sugerem que a fusão com lisossomos e acidificação do vacúolo parasitóforo causa a destruição dos parasitos na presença de hidroxiuréia.

Palavras-chave: Hidroxiuréia, Toxoplasma gondii, vacúolo parasitóforo.

\section{REFERENCES}

BEYER TV, SUEZHOVA NV, RADCHENKO A AND SidorEnKo NV. 2002. Parasitophorous vacuole morphofunctional diversity in different coccidian genera (a short insight into the problem). Cell Biol Int 26: 861-871.
Finlay BB AND Falkow S. 1989. Common themes in microbial pathogenicity. Microbiol Rev 53: 210230.

Hill D AND Dubey JP. 2002. Toxoplasma gondii: transmission, diagnosis and prevention. Clin Microbial Infect 68: 634-640.

HiRsCH JG AND JONES TC. 1972. The interaction between Toxoplasma gondii and mammalian cells. II. The absence of lysosomal fusion with phagocytic vacuoles containing living parasites. J Exp Med 136: 1173-1194.

Horwitz MA. 1984. Phagocitosis of the Legionaires disease bacterium (Legionella pneumophila) ocurrs by a novel mechanism: engulfment within a pseudopod coil. Cell 36: 27-33.

Joiner KA, Furhman SA, Miettinen HM, KasPER LH AND MELlMAN T. 1990. Toxoplasma gondii: fusion competence of parasitophorous vacuole in Fc-receptor transfected fibroblasts. Science 249: 641-646.

Kielian MC AND CoHn ZA. 1980. Phagosome-lysosome fusion. J Cell Biol 85: 54-765.

Kornfeld S And Mellman I. 1989. The biogenesis of lysosomes. Annu Rev Cell Biol 5: 483-525.

Magez S, Geuskens M, Beschin A, Favero H, Verschueren H, LuCAS R, PAys E ANd BAETSELIER P. 1997. Specific uptake of tumor necrosis factor- $\alpha$ is involved in growth control of Trypanosoma brucei. J Cell Biol 137: 715-727.

Matsumoto A, Bessho I, Uehirak K And SudA T. 1991. Morphological studies of the association of mitochondria with Chlamydial inclusions and the fusion of Chlamydial inclusions. J Electron Microsc 40: $356-363$.

Melo EJT And BeIRAL HJ. 2003. Effect of hydroxyurea on the intracellular multiplication of Toxoplasma gondii, Leishmania amazonensis and Trypanosoma cruzi. Braz J Med Biol Res 36: 65-69.

Melo EJT AND DE SouzA W. 1996. Pathway of C6NBD-Ceramide on the host cell infected with Toxoplasma gondii. Cell Struct Funct 21: 47-52.

Melo EJT And De Souza W. 1997. Relationship between the host cell endoplasmic reticulum and the parasitophorous vacuole containing Toxoplasma gondii. Cell Struct Funct 22: 317-323. 
Melo EJT, Carvalho TMU And De Souza W. 1992. Penetration of Toxoplasma gondii into host cells induces changes in the distribution of the mitochondria and the endoplasmic reticulum. Cell Struct Funct 17: 311-317.

Melo EJT, Mayerhoffer RO AND de Souza W. 2000. Hydroxyurea inhibits intracellular Toxoplasma gondii multiplication. FEMS Microbiolgy Letters 185: 79-82.

Melo EJT, Carvalho TMU and de Souza W. 2001. Behaviour of microtubules in cells infected with Toxoplasma gondii. BIOCELL 25: 53-59.

Mordue DG, HaKAnsSon S, NiESMAn I AND SIBLEY D. 1999a. Toxoplasma gondii resides in a vacuole that avoids fusion with host cell endocytic and exocytic vesicular trafficking pathways. Exp Parasitol 92: 87-99.

ROBINSON JM AND KARNOVSKY M. 1983. Ultrastructural localization of several phsophatases with cerium. J Histochem Cytochem 10: 1197-1208.

SIBLEY LD. 1993. Interaction between Toxoplasma gondii and its mammalian host cells. Seminars in Cell Biol 4: 335-344.
Sibley LD, Weidner E AND Krahenbuhl JL. 1985. Phagosome acidification blocked by intracellular Toxoplasma gondii. Nature 315: 416-419.

SINAI AP AND JOINER KA. 1997. Safe haven: the cell biology of nonfusogenic pathogen vacuoles. Annu Rev Microbiol 51: 415-462.

SinAI AP, Webster P AND JoIner KA. 1997. Association of host cell mitochondria and endoplasmic reticulum with the Toxoplasma gondii parasitophorous vacuole. J Cell Sci 110: 2117-2128.

SWANSON J. 1989. Fluorescent labeling of endocytic compartments. Methods Cell Biol 29: 137-151.

Tenter AM, Heckeroth AR AND WeIss LM. 2000. Toxoplasma gondii: from animals to human. Int J Parasitol 30: 1217-1258.

TJeire TE, Lovdai T And Berg T. 2000. Phagosome dynamics and function. BioEssays 22: 255-263.

Tuma P, Nyasae LK, Backer JM AND Hubbard AL. 2001. Vps34 differentially regulates endocytosis from the apical and basolateral domains in polarized hepatic cells. J Cell Biol 154: 1197-1208.

YARBRO JW. 1992. Mechanism of action of hydroxyurea. Seminars in Oncology 19: 1-10. 